\title{
NEW PROPOSAL FOR EUROPEAN UNION REGULATIONS ON MEDICAL DEVICES AND IN VITRO DIAGNOSTIC MEDICAL DEVICES
}

\author{
Mariela Yaneva-Deliverska, \\ Ministry of Justice, International legal co-operation and European \\ affairs directorate, Sofia, Bulgaria.
}

\section{SUMMARY:}

Appropriate legislation is fundamental to ensuring the highest level of health protection and effective innovation. Until the 1990s, each European Union country had its own approach to device evaluation but governments needed to put in place policies that will address all elements related to medical devices, ranging from access to high quality, affordable products, through to their safe and appropriate use and disposal.

In order to ensure that patients, consumers and healthcare professionals can reap the benefits of safe, effective and innovative medical devices, the European Commission has proposed two new Regulations. The first proposal is for Regulation on medical devices and is to replace Directive 90/385/EEC regarding active implantable medical devices and Directive 93/42/EEC regarding medical devices, while the second proposal is for a Regulation on in vitro diagnostic medical devices and is to replace Directive 98/79/EC.

The proposed Regulations foresee to amend and clarify the scope of the legislation, to take into account scientific and technological progress

Key words: Medical devices, legislation, innovation, patients, healthcare professionals

Medical technology and services, including a large and highly skilled workforce, play a crucial role in keeping the European population healthy and productive through delivering innovation into healthcare, while also contributing to the European knowledge-based economy. The term medical device covers a vast range of equipment, from simple tongue depressors to haemodialysis machines. With innovation and the rapid advancement of technologies, medical devices are currently one of the fastest growing industries.

Appropriate legislation is fundamental to ensuring the highest level of health protection and effective innovation. It is also necessary for the good functioning of the internal market, which represents a major source of growth and jobs, and the effectiveness of European Union's external trade. Until the 1990s, each European Union country had its own approach to device evaluation but governments needed to put in place policies that will address all elements related to medical devices, ranging from access to high quality, affordable products, through to their safe and appropriate use and disposal.

The main European legal framework related to medical devices consists of three directives that regulate the safety and marketing of medical devices in Europe, the first one of which came into effect in the 1990s. On June 20, 1990 the Council of the European Communities adopts [1] Council Directive 90/385/EEC on the approximation of the laws of the Member States relating to active implantable medical devices. Three years later Directive 93/42 EEC concerning medical devices [2] was adopted and it applies to medical devices and their accessories. Directive applicable to in vitro diagnostic medical devices and their accessories was adopted in 1998 [3].

Since their adoption, these three legal acts have been supplemented and in 2007 Directive 2007/47/EC [4] was adopted, which amends Council Directive 90/ $385 /$ EEC on the approximation of the laws of the Member States relating to active implantable medical devices, Council Directive 93/42/EEC concerning medical devices and Directive 98/8/EC concerning the placing of biocidal products on the market.

There has been recognized the need of modernization and strengthening the current medical devices legislation in Europe due to the fact that the medical device sector is highly innovative. The medical device legislation has to be able to answer the needs of tomorrow with the aim to achieve a suitable, robust, 
transparent and sustainable regulatory framework. In order to ensure that patients, consumers and healthcare professionals can reap the benefits of safe, effective and innovative medical devices, the European Commission has proposed two new Regulations. The first proposal is for Regulation on medical devices and is to replace Directive 90/385/EEC regarding active implantable medical devices and Directive 93/42/EEC regarding medical devices, while the second proposal is for a Regulation on in vitro diagnostic medical devices and is to replace Directive 98/79/EC. The proposed Regulations foresee to amend and clarify the scope of the legislation, to take into account scientific and technological progress and respond to tomorrow's needs.

The scope of the proposed Regulation on in vitro diagnostic medical devices to a large extend matches the the scope of Directive 98/79/EC. Some of the proposed changes concern high-risk devices manufactured and used within a single health institution, which are subject to most of the requirements set out in the proposal. As in vitro diagnostic medical devices are considered tests providing information about the predisposition to a medical condition or a disease (e.g. genetic tests) and tests providing information to predict treatment response or reactions (e.g. companion diagnostics).

The scope of the proposed Regulation on medical devices corresponds to a large extent to the combined scopes of Council Directives 90/385/EEC and 93/42/EEC and covers all medical devices other than in vitro diagnostic medical devices, but it also covers some products currently not covered by both directives. The extension of the scope concerns products manufactured utilizing non-viable human tissues or cells, or their derivatives that have undergone substantial manipulation unless they are covered by Regulation (EC) No 1394/ 2007 on advanced therapy medicinal products [5]. The scope also covers certain implantable or other invasive products without a medical purpose that are similar to medical devices in terms of characteristics and risk profile.

Human tissues and cells, or products derived from human tissues or cells, that are not substantially manipulated and that are regulated by Directive 2004/ 23/EC of the European Parliament and of the Council of 31 March 2004 on setting standards of quality and safety for the donation, procurement, testing, processing, preservation, storage and distribution of human tissues and cells [6] are not covered by the proposal.
The new approach in both proposed Regulations will be beneficial to patients and consumers, to the health care professionals and to the manufacturers since there will be clear rules easier trading between EU countries and a level playing field that excludes those who do not comply with the legislation. The new rules support patient-oriented innovation and take particular account of the specific needs of the many small and mediumsized manufacturers in this sector. All devices will have to undergo thorough assessment of safety and performance before they can be sold on the European market. Control processes are radically reinforced, but continue to ensure rapid access to innovative, costeffective devices for European patients and consumers. The proposed Regulations aim to strengthen the supervision of the notified bodies by the Member States, in order to ensure that all bodies have the necessary competence to carry out the pre-market assessment of devices.

Both new Regulations will guarantee the independency and the quality of pre-market assessment of devices, by clarifying and enhancing the position and powers of notified bodies vis-a-vis the manufacturers and by providing an appropriate level of intervention of public authorities. They aim to clarify the obligations and responsibilities of manufacturers, importers and distributors and to ensure transparency.

The proposal for both Regulations shall enter into force on the twentieth day after its publication in the Official Journal of the European Union. The proposal for Regulation on medical devices shall apply from three years after entry into force, while the proposal for a Regulation on in vitro diagnostic medical devices shall apply from five years after entry into force. The Commission proposals are expected to be adopted in 2014 and would then gradually come into effect from 2015 to 2019.

The proposed Regulations will allow the European Union to continue to ensure a high level of health protection and counteract emerging doubts and decreased confidence of patients, consumers and healthcare professionals in medical devices and in vitro diagnostic medical devices, while at the same time fostering innovation and competitiveness of these two sectors. They will reinforce the rules governing clinical evaluation throughout the life of medical devices and in vitro diagnostic medical devices. 


\section{REFERENCES:}

1. Commission communication in the framework of the implementation of the Council Directive 90/385/EEC of 20 June 1990 on the approximation of the laws of the Member States relating to active implantable medical devices. Official Journal of the European Union. C262, 30 Aug 2012; 55:1-5.

2. Council Directive 90/385/EEC of 20 June 1990 on the approximation of the laws of the Member States relating to active implantable medical devices. Official Journal of the European Union. L189, 20 Jul 1990; 33:17-36.

3. Directive $98 / 79 / \mathrm{EC}$ of the European Parliament and of the Council of 27 October 1998 on in vitro diagnostic medical devices. Official Journal of the European Union. L331, 7 Dec 1998; 41:1-37.

4. Directive $2007 / 47 /$ EC of the European Parliament and of the Council of 5 September 2007 amending Council Directive 90/385/EEC on the approximation of the laws of the Member States relating to active implantable medical devices, Council Directive 93/42/EEC concerning medical devices and Directive 98/8/EC concerning the placing of biocidal products on the market, Official Journal of the European Union. L247; 21 Sep 2007; 50:21-55.

5. European Commission, Safe, effective and innovative medical devices and in vitro diagnostic medical devices for the benefit of patients, consumers and healthcare professionals. COM(2012) 540 final

6. European Commission, Proposal for a Regulation of the European parliament and of the Council on medical devices, and amending Directive 2001/83/EC, Regulation (EC) No 178/2002 and Regulation (EC) No 1223/2009, COM(2012) 542 final.

7. European Commission, Proposal for a Regulation of the European parliament and of the Council on in vitro diagnostic medical devices, COM(2012) 541 final.

Address for correspondence:

Mariela Yaneva-Deliverska, PhD /Doctor of International Law and International Relations/

Mobile: +359887574973

E-mail: yanevamariela@yahoo.com; 